\title{
NOWELIZACJA USTAWY O PRZECIWDZIALANIU NARKOMANII W TRZY LATA PO JEJ WEJŚCIU W ŻYCIE - RAPORT Z PRAKTYKI STOSOWANIA
}

Streszczenie. Niniejsze opracowanie stanowi próbę oceny, jak w praktyce funkcjonują instytucje wprowadzone nowelizacją ustawy o przeciwdziałaniu narkomanii z 1 kwietnia $2011 \mathrm{r}$. Najważniejszą zmianą nowelizacji było dodanie do ustawy art. 62a, dającego prokuratorowi oraz sądowi możliwość umorzenia postępowania karnego wobec sprawcy posiadającego nieznaczne ilości środków odurzających lub substancji psychotropowych, przeznaczonych na jego własny użytek. Ponadto, nowelizacja rozszerzyła katalog alternatywnych środków o charakterze leczniczym, realizując zasadę „leczyć zamiast karać”.

Raport sporządzony został na podstawie wszelkich dostępnych danych statystycznych, przekazanych przez: sądy, Prokuraturę Generalną i - przede wszystkim - Ministerstwo Sprawiedliwości. W ramach prac nad raportem przeprowadzone zostały także wywiady z praktykami stosującymi przepisy nowelizacji (policjantem, prokuratorem i adwokatem) oraz przedstawicielką Ministerstwa Sprawiedliwości.

Przedstawione dane statystyczne wskazują, że liczba umorzeń spraw o posiadanie narkotyków, w tym umorzeń na podstawie art. 62a u.p.n., jest wciąż stosunkowo mała. Głównym postulatem płynącym z niniejszego raportu jest zatem konieczność opracowania przez Prokuratora Generalnego stosownych wartości granicznych dla poszczególnych substancji psychoaktywnych, definiujących pojęcie ich „nieznacznej ilości”.

Słowa kluczowe: narkotyki, nowelizacja, posiadanie, kryminalizacja, przeciwdziałanie narkomanii.

\section{WYKAZ SKRÓTÓW}

HFPC - Helsińska Fundacja Praw Człowieka.

k.k. - ustawa z dnia 6 czerwca 1997 r. - Kodeks karny (Dz. U. 1997, Nr 88, poz. 553 ze zm.).

k.p.k. - ustawa z dnia 6 czerwca 1997 r. - Kodeks postępowania karnego (Dz. U. 1997, Nr 89, poz. 555 ze zm.).

* Prawnik, koordynator Programu Interwencji Prawnej Helsińskiej Fundacji Praw Człowieka. Autor badań zawierających szczegółową analizę spraw sądowych dotyczących popełnienia czynu określonego w art. 62 Ustawy o przeciwdziałaniu narkomanii oraz współautor komentarza do wybranych przepisów karnych ustawy. p.kubaszewski@hfhr.org.pl. 
nowelizacja - ustawa z dnia 1 kwietnia 2011 r. o zmianie ustawy o przeciwdziałaniu narkomanii oraz niektórych innych ustaw (Dz. U. 2011, Nr 117, poz. 678).

SR - Sąd Rejonowy.

u.p.n. - ustawa z dnia 29 lipca 2005 r. o przeciwdziałaniu narkomanii (Dz. U. 2012, poz. 124).

\section{TEZY}

1. Nowelizację ustawy o przeciwdziałaniu narkomanii z 1 kwietnia $2011 \mathrm{r}$. zdecydowanie uznać należy za krok w dobrym kierunku.

2. Liczba umorzeń spraw o posiadanie narkotyków, w tym umorzeń na podstawie art. 62a u.p.n. - najważniejszej zmiany nowelizacji - jest jednak wciąż stosunkowo mała.

3. Nieprecyzyjnie sformułowany przepis stanowiący podstawę umorzenia w połączeniu z jego fakultatywnym charakterem powoduje, że art. 62a u.p.n. znacznie przegrywa ze skazaniami w ramach tzw. konsensualnych form zakończenia postępowania.

4. Przesłanki, od spełnienia których zależy możliwość umorzenia postępowania na podstawie art. 62a u.p.n., mają charakter ocenny i nie zostały w żaden sposób zdefiniowane.

\section{POSTULATY}

1. Opracowanie przez Prokuratora Generalnego stosownych wartości granicznych dla poszczególnych substancji psychoaktywnych, definiujących pojęcie ich „nieznacznej ilości”. Stanowić ono będzie dokończenie procesu nowelizacji i pozwoli na zakładane przez projektodawcę umarzanie drobnych spraw związanych z posiadaniem narkotyków, na jak najwcześniejszym etapie postępowania.

2. Wydanie przez Prokuratora Generalnego wytycznych, aby w każdym przypadku, w którym zachodzą przesłanki przewidziane w art. 62a u.p.n, postępowanie było umarzane, chyba że zachodziłaby jakaś nadzwyczajna okoliczność (okoliczność ta powinna zostać szczegółowo uzasadniona).

3. Ponowne rozważenie przez ustawodawcę propozycji HFPC dotyczącej wprowadzenia na poziomie u.p.n. domniemania celu posiadania nieznacznej ilości narkotyku „na własne potrzeby”, jeżeli okoliczności nie wskazują na cel handlowy. 


\section{UWAGI WSTĘPNE}

\subsection{Wprowadzenie}

Niniejsze opracowanie stanowi próbę oceny praktyki stosowania instytucji wprowadzonych nowelizacją ustawy o przeciwdziałaniu narkomanii z dnia 1 kwietnia 2011 r., która weszła w życie 9 grudnia 2011 r. (dalej: „,nowelizacja”). Projekt nowelizacji, autorstwa Ministerstwa Sprawiedliwości, opracowany został przez powołany w tym celu zespół ekspertów, któremu przewodniczyła Barbara Wilamowska - Koordynator Ministra Sprawiedliwości ds. Krajowego Programu Przeciwdziałania Narkomanii. W skład zespołu wchodził m.in. prof. Krzysztof Krajewski (Uniwersytet Jagielloński), którego badania aktowe stanowiły jeden z filarów przeprowadzonej zmiany u.p.n.

Najważniejszą zmianą nowelizacji było dodanie do ustawy art. 62a, dającego prokuratorowi oraz sądowi możliwość umorzenia postępowania karnego wobec sprawcy posiadającego nieznaczne ilości środków odurzających lub substancji psychotropowych, przeznaczonych na jego własny użytek. Ponadto, nowelizacja rozszerzyła katalog alternatywnych środków o charakterze leczniczym, realizując zasadę „leczyć zamiast karać”. Stanowi ona zatem odejście od restrykcyjnego modelu zapobiegania narkomanii ku modelowi permisywnemu (Kładoczny, Wilamowska, Kubaszewski 2013, 24-32).

Pierwotna wersja raportu została opublikowana 9 grudnia 2014 r. (w trzecią rocznicę wejścia w życie nowelizacji) na stronie internetowej HFPC. Opracowanie stanowi jeden $\mathrm{z}$ wielu tzw. policy paper, powstałych $\mathrm{w}$ ramach progra$\mathrm{mu}$ „Monitoring procesu legislacyjnego w obszarze wymiaru sprawiedliwości”, których idea opiera się na weryfikacji założeń legislacyjnych przyjętych w fazie projektowania zmiany ustawy.

\subsection{Metodologia raportu}

Raport sporządzony został na podstawie wszelkich dostępnych w tej chwili danych statystycznych, przekazanych przez: sądy, Prokuraturę Generalną i - przede wszystkim - Ministerstwo Sprawiedliwości. W ramach prac nad raportem przeprowadzone zostały także wywiady z praktykami stosującymi przepisy nowelizacji (policjantem, prokuratorem i adwokatem) oraz Barbarą Wilamowską z Ministerstwa Sprawiedliwości.

$\mathrm{Na}$ wnioski Helsińskiej Fundacji Praw Człowieka o udostępnienie informacji publicznej pozytywnie odpowiedziały wszystkie organy wymiaru 
sprawiedliwości, z wyjątkiem Sądu Rejonowego w Rybniku ${ }^{1}$ Komenda Główna Policji poinformowała nas z kolei, że nie gromadzi danych dotyczących liczby zatrzymań i przeszukań (osobistych i pomieszczeń) dokonanych przez Policję w związku z podejrzeniem popełnienia czynu z art. 62 u.p.n.

\section{ZAKRES PRZEDMIOTOWY NOWELIZACJI}

\subsection{Potrzeba zmian}

Zwolennicy kryminalizacji posiadania jakiejkolwiek ilości narkotyków powołują się na argumenty dwojakiego rodzaju (Krajewski 1992, 49-57). Po pierwsze, ma ona stanowić istotną przesłankę zwalczania nielegalnej podaży substancji psychoaktywnych, jako forma efektywnej walki z handlarzami narkotyków. Z drugiej zaś strony, kryminalizacja posiadania narkotyków ma oddziaływać na zmniejszenie popytu, głównie poprzez odstraszanie potencjalnych nabywców. Powyższe argumenty poddawane są krytyce przez zwolenników permisywnego modelu zapobiegania narkomanii.

\section{Art. 62.}

1. Kto, wbrew przepisom ustawy, posiada środki odurzające lub substancje psychotropowe, podlega karze pozbawienia wolności do lat 3 .

2. Jeżeli przedmiotem czynu, o którym mowa w ust. 1, jest znaczna ilość środków odurzających lub substancji psychotropowych, sprawca podlega karze pozbawienia wolności od 1 roku do lat 10 .

3. W wypadku mniejszej wagi, sprawca podlega grzywnie, karze ograniczenia wolności albo pozbawienia wolności do roku.

W ramach badań przeprowadzonych przez Instytut Spraw Publicznych (Kuźmicz, Mielecka-Kubień, Wiszejko-Wierzbicka 2009), przedstawicielom organów wymiaru sprawiedliwości zadane zostały m.in. trzy następujące pytania:

1. Czy art. 62 u.p.n. jest skutecznym narzędziem w ograniczaniu handlu narkotykami?

2. Czy art. 62 u.p.n. jest skutecznym narzędziem odstraszającym potencjalnych użytkowników (osoby, które jeszcze nie zażywały narkotyków)?

${ }^{1}$ Wniosek o udostępnienie informacji w zakresie liczby osądzonych osób z art. 62 oraz art. 62a u.p.n. w latach 2010-2013 oraz liczby przypadków, w których w ww. sprawach oskarżonemu przyznany został obrońca z urzędu, Prezes Sądu Rejonowego w Rybniku uznał za informacje przetworzone i wezwał HFPC do wykazania, iż ich uzyskanie jest szczególnie istotne dla interesu publicznego. 
3. Czy art. 62 u.p.n. jest skutecznym narzędziem do ograniczenia używania narkotyków wśród osób, które już używają narkotyków?

Z odpowiedzi udzielonych na pierwsze pytanie wynika, iż art. 62 u.p.n. nie stanowi pomocnego narzędzia $\mathrm{w}$ walce $\mathrm{z}$ handlem narkotykami. Ze stwierdzeniem, że przepis ten jest skutecznym narzędziem w ograniczaniu handlu narkotykami, nie zgodziło się: $48 \%$ policjantów ( $6 \%$ nie miało zdania), $60 \%$ prokuratorów ( $8 \%$ nie miało zdania), 45\% sędziów (17\% nie miało zdania) i 56\% kuratorów sądowych (13\% nie miało zdania) (Kuźmicz, Mielecka-Kubień, Stasiowski, Wiszejko-Wierzbicka 2009, 5). Ze stwierdzeniem, jakoby art. 62 u.p.n. był skutecznym narzędziem odstraszającym potencjalnych użytkowników, nie zgodziło się: $51 \%$ policjantów ( $7 \%$ nie miało zdania), $66 \%$ prokuratorów ( $6 \%$ nie miało zdania), 46\% sędziów (19\% nie miało zdania) oraz 58\% kuratorów sądowych (12\% nie miało zdania) (tamże, 6). Natomiast na pytanie, czy art. 62 u.p.n. jest skutecznym narzędziem dla ograniczenia używania narkotyków wśród osób, które już je używają, negatywnie odpowiedziało: 48\% policjantów (11\% nie miało zdania), $52 \%$ sędziów (15\% nie miało zdania), $61 \%$ prokuratorów (12\% nie miało zdania) i $57 \%$ kuratorów sądowych (14\% nie miało zdania). Ogólna tendencja dostrzeżona w badaniach wskazuje więc na sceptycyzm policjantów, prokuratorów, sędziów oraz kuratorów sądowych wobec uznania karania za posiadanie narkotyków za skuteczne narzędzie prewencyjne zarówno wśród osób, które jeszcze ich nie próbowały, jak i wśród okazjonalnych użytkowników (tamże, 6-7).

K. Krajewski, odnosząc się do nowelizacji ustawy o przeciwdziałaniu narkomanii przeprowadzonej w 2000 r. (Ustawa z dnia 26 października 2000 r.) $)^{2}$, wskazuje, iż spowodowała ona dramatyczny wzrost rozmiarów ujawnionej w statystyce policyjnej przestępczości narkotykowej, której znaczną część stanowią czyny polegające na posiadaniu niewielkich ilości narkotyków, przeznaczonych na własny użytek (Krajewski 2007, 434). W konsekwencji, duża część sił i środków Policji została skierowana w zupełnie niewłaściwym kierunku - ścigania drobnych przestępstw narkotykowych, niemających większego znaczenia dla redukcji nielegalnej podaży narkotyków. Zdaniem K. Krajewskiego, nic nie wskazuje, aby „,pełna” kryminalizacja rzeczywiście ułatwiała Policji walkę z dilerami narkotyków, a więc powodowała zmniejszenie podaży substancji psychoaktywnych. Tezę tę potwierdzają badania przeprowadzone wśród młodzieży szkolnej w ramach międzynarodowego programu badawczego ESPAD (European School Survey Project on Alcohol and Drugs) z lat 1999, 2003 oraz 2005 (Sierosławski

${ }^{2}$ Ustawodawca zrezygnował wówczas z okoliczności wyłączającej karalność, jaką było posiadanie nieznacznych ilości narkotyków przeznaczonych na własny użytek. Od tej pory posiadanie każdej ilości środków odurzających lub substancji psychotropowych stało się czynem zabronionym pod groźbą kary, ściganym z urzędu. 
2005; Sierosławski 2004, 17-55; Serwis Informacyjny Narkomania, 3). Z badań wynika, że w ocenie uczniów dostępność narkotyków po 2000 roku nie zmniejszyła się, a w niektórych przypadkach nawet wzrosła.

Przyjęty wcześniej model restrykcyjny został jednoznacznie skrytykowany w uzasadnieniu do projektu nowelizacji z roku 2011 (Sejm VI kadencji. Uzasadnienie...). Na podstawie przeprowadzonych badań i analiz danych statystycznych gromadzonych przez Wydział Statystyki MS, sformułowany został wniosek, że założenia legislacyjne w zakresie ograniczenia konsumpcji narkotyków w Polsce nie zostały dotychczas zrealizowane. Ponadto, doprowadziły one do powstania dwóch niekorzystnych zjawisk społeczno-prawnych. Po pierwsze, udaremniły organom ścigania penetrację środowiska osób zajmujących się wprowadzaniem do obrotu substancji odurzających. Po drugie, „powołały do życia” nową kategorię przestępców, jakimi stały się osoby uzależnione i używające narkotyków (tamże, 1). Zgodnie z obowiązującą w Polsce od 1996 r. Międzynarodową Klasyfikacją Chorób i Problemów Zdrowotnych ICD-103, uzależnienie od substancji psychoaktywnych - podobnie jak uzależnienie od alkoholu - jest jednostką chorobową ${ }^{4}$.

W uzasadnieniu nowelizacji zauważono, że - pomimo zaostrzenia polityki karnej w 2000 r. - nie został osiągnięty zakładany wówczas przez ustawodawcę wzrost wykrywalności przestępstw wytwarzania, przetwarzania, wprowadzania do obrotu czy chociażby udzielania substancji psychoaktywnych. Jak wskazał projektodawca, „w tych właśnie obszarach aktywności organów ścigania obserwujemy istotną stagnację, czy nawet regres" (Sejm VI kadencji. Uzasadnienie..., 2).

W uzasadnieniu nowelizacji wskazano ponadto, że na ogólną liczbę 26935 skazań na podstawie ustawy o przeciwdziałaniu narkomanii w 2005 r. aż 17588 zakończyło się orzeczeniem kary pozbawienia wolności. „Penalizacja posiadania środków odurzających - wbrew założeniom - stała się zatem narzędziem kryminalizacji używania, a nie przeciwdziałania narkomanii” (tamże, 2). W uzasadnieniu nowelizacji zauważono jednocześnie, iż zgodnie z badaniami Instytutu Spraw Publicznych, realizacja art. 62 u.p.n. kosztuje Skarb Państwa 79,2 mln zł rocznie (Kuźmicz, Mielecka-Kubień, Wiszejko-Wierzbicka 2009).

Instytut Spraw Publicznych oszacował, iż w 2008 r. pracownicy organów ścigania i wymiaru sprawiedliwości, na pracę związaną ze sprawami z art. 62 u.p.n., poświęcili 1631 377,2 godzin, co stanowi ok. 203900 ośmiogodzinnych dni roboczych (Kuźmicz, Mielecka-Kubień, Stasiowski, Wiszejko-Wierzbicka $2009,8)$. Na jednego ukaranego za przestępstwo z art. 62 u.p.n. przypadał średnio koszt w wysokości co najmniej 687300 zł oraz 1764,4 ośmiogodzinnych dni pracy pracowników organów ścigania i wymiaru sprawiedliwości. Koszty te zostały obliczone na podstawie:

\footnotetext{
${ }^{3}$ ICD-10 została opracowana przez Światową Organizację Zdrowia (WHO).

${ }^{4}$ Kategoria F - Zaburzenia psychiczne i zaburzenia zachowania.
} 
- relacji czasu pracy poświęconego na realizację spraw z art. 62 u.p.n. przez policjantów, prokuratorów, sędziów, kuratorów sądowych i funkcjonariuszy Służby Więziennej do ich zarobków;

- kosztów ekspertyz zlecanych w związku ze sprawami z art. 62;

- kosztów wykonania wyroków zasądzonych z art. 62 (koszty więziennictwa);

- kwot grzywien zasądzonych w tych sprawach odjętych od sumy ww. kosztów (tamże, 8, przyp. 10).

W uzasadnieniu nowelizacji dostrzeżono, że obowiązujący model restrykcyjny negatywnie wpłynął na działania o charakterze terapeutycznym oraz leczniczym, podejmowane wobec użytkowników, jak i osób uzależnionych od narkotyków. Represja, spychając użytkowników narkotyków do podziemia, utrudniła bowiem realizację efektywnej polityki socjalnej i zdrowotnej wobec tych osób, powodując trudności w dostępie do nich służb socjalnych i medycznych (Krajewski 2007, 427). Narkomani unikają kontaktów ze światem zewnętrznym z ciągłej obawy, że mogą one spowodować pociągnięcie ich do odpowiedzialności karnej. Dotyczy to, oprócz Policji, także pracowników socjalnych, lekarzy oraz terapeutów, co jest niewątpliwym utrudnieniem dla wytworzenia stosunku zaufania pomiędzy użytkownikiem a terapeutą - stanowiącego warunek konieczny do pomyślnego zakończenia terapii.

W świetle przedstawionego powyżej stanu rzeczy, ustawodawca uznał za konieczne przeprowadzenie zmian realizujących zasadę „leczyć zamiast karać”.

\title{
2.2. Art. $62 \mathrm{a}$ - oportunizm ścigania
}

\begin{abstract}
Wyniki badań empirycznych zawarte w uzasadnieniu projektu wskazywały, iż „olbrzymia większość spraw o przestępstwa z art. 62 ust. 1 lub 2 ustawy o przeciwdziałaniu narkomanii dotyczy posiadania dwóch środków, a mianowicie marihuany oraz amfetaminy, przy czym znaczna ich część to sprawy drobne, a nawet niezwykle drobne, dotyczące posiadania bardzo niewielkich ilości przeznaczonych ewidentnie na cele własnej konsumpcji. W wielu takich sprawach, które w Polsce kończą się wyrokami skazującymi, chodzi o ilości środków, które w innych krajach UE są prawnie irrelewantne i umożliwiają stosowanie oportunizmu ścigania. Tymczasem w Polsce sprawy te angażują sporą ilość czasu, sił i środków Policji, prokuratury oraz sądów, a równocześnie można mieć zasadnicze wątpliwości co do korzyści, jakie przynoszą one z punktu widzenia zasadniczego celu stosowania represji karnej w obszarze przeciwdziałania narkomanii, tj. redukcji rozmiarów nielegalnej podaży środków odurzających i substancji psychotropowych (redukcja rozmiarów popytu to przede wszystkim, aczkolwiek nie wyłącznie, zadanie profilaktyki, leczenia, rehabilitacji i readaptacji)".
\end{abstract}

W związku z powyższym, autorzy projektu nowelizacji zdecydowali się na dodanie art. 62a, który przyznał prokuratorom oraz sądom kompetencje do umorzenia postępowania karnego wobec sprawcy posiadającego nieznaczne ilości środków odurzających lub substancji psychotropowych, przeznaczonych na jego 
własny użytek. Umorzenie możliwe jest jednak wyłącznie w sytuacji, jeżeli orzeczenie wobec sprawcy kary byłoby niecelowe ze względu na okoliczności popełnienia czynu, a także stopień jego społecznej szkodliwości. Ustanowiona została zatem generalna przesłanka, wskazująca na niecelowość stosowania represji karnej wobec pewnej grupy osób posiadających narkotyki.

W uzasadnieniu nowelizacji wyrażone zostało przekonanie, iż warunki konieczne do umorzenia postępowania - nieznaczna ilość narkotyków oraz ich przeznaczenie (własny użytek) - są ze sobą ściśle powiązane. W przypadku posiadania nieznacznych ilości środków odurzających lub substancji psychotropowych, jeżeli brak dowodów wskazujących na przeznaczenie na cele handlowe, przyjmować należy cel w postaci własnego użytku (tamże, 13). Kwestię tę dwukrotnie poruszała Helsińska Fundacja Praw Człowieka w swoich opiniach, przedstawionych w toku prac legislacyjnych nad nowelizacją w ramach konsultacji społecznych (Opinia z dnia 18 grudnia 2009; Opinia z dnia 22 lutego 2011). Fundacja wskazała, iż przedstawiona interpretacja jest jedynie życzeniem projektodawcy, a nie stwierdzeniem ustawowym. Wykładnia tego przepisu przez organy ścigania i wymiaru sprawiedliwości pójść może jednak w zupełnie innym kierunku - wówczas konieczność przeprowadzenia takiego dowodu spoczywałaby na posiadaczu substancji psychoaktywnej, co nie zawsze byłoby możliwe. Zdaniem HFPC, rozważyć należało zatem taki sposób sformułowania przepisu, który wprost precyzowałby pożądaną przez autorów projektu interpretację. Rozwiązaniem byłoby wprowadzenie zapisu wskazującego na domniemanie takiego właśnie celu posiadania nieznacznej ilości narkotyku „na własne potrzeby”, jeśli okoliczności nie wskazują na cel handlowy. Propozycja ta nie spotkała się jednak z aprobatą ustawodawcy.

\footnotetext{
Autorzy projektu zrezygnowali z bliższego definiowania pojęcia „nieznacznej ilości” środka odurzającego lub substancji psychotropowej, pozostawiając to każdorazowej ocenie prokuratora lub sądu (jak to jest w przypadku znamienia „znacznej ilości” narkotyków, występującego w u.p.n.). W uzasadnieniu do nowelizacji zauważono, że „rozwiązanie takie może oczywiście nastręczać pewne trudności w praktyce. Biorąc jednak pod uwagę złożony i skomplikowany z legislacyjnego punktu widzenia charakter ewentualnego bliższego zdefiniowania tego znamienia (musiałby on przyjąć formę rozbudowanego załącznika do ustawy), wydaje się, że pozostanie przy ocennym charakterze tego znamienia jest rozwiązaniem akceptowalnym. Natomiast wskazówką dla organów stosujących prawo (przede wszystkim organów prokuratury) mogą tu być wewnętrzne wytyczne wskazujące stosowne wartości graniczne. Taka praktyka rozwiązania tego problemu jest stosowana w wielu krajach europejskich".
}

Istotną wartością nowelizacji, zdaniem projektodawcy, jest każdorazowa ocena przez organ prowadzący postępowanie, czy dany przypadek spełnia przesłanki konieczne do umorzenia postępowania. Brak automatyzmu zagwarantować miał indywidualne podejście, a tym samym realizację również innych celów prawa 
karnego (m.in. prewencja generalna, cele terapeutyczne) w przypadkach, które na to zasługują (tamże, 15-16). Celowo nie powrócono do depenalizacji posiadania niewielkich ilości narkotyków przeznaczonych na własny użytek. Dlatego też w nowelizacji nie pojawiło się stwierdzenie, że sprawy tego typu nie powinny być w ogóle wszczynane, wszczęte zaś - powinny zostać umorzone. W tym kontekście wskazać należy na swoistą niekonsekwencję projektodawcy w zakresie założonych celów i środków przyjętych do ich realizacji. Z jednej strony, umorzenie postępowania w oparciu o art. 62a u.p.n. ma charakter fakultatywny, a wymienione w tym przepisie przesłanki nie stoją na przeszkodzie wszczęciu postępowania. Okoliczności wymienione w art. 62a ustawy o przeciwdziałaniu narkomanii nie stanowią więc negatywnych przesłanek procesowych, oznaczających obligatoryjność niewszczynania lub umorzenia postępowania. $Z$ drugiej zaś strony, zgodnie z uzasadnieniem projektu nowelizacji, jego intencją było niedopuszczenie, aby sprawy o posiadanie nieznacznej ilości narkotyków przekształcały się w ,normalne" postępowania przygotowawcze, co „wykluczyłoby możliwość osiągnięcia spodziewanych efektów nowelizacji w zakresie ekonomii postępowania" (tamże, 15). Pożytki płynące ze ścigania takich czynów i sprawców uznano za wątpliwe, a zwolnione siły i środki organów wymiaru sprawiedliwości miały zostać spożytkowane w innych obszarach. Dlatego też art. 62a u.p.n. zawiera sformułowanie ,postępowanie można umorzyć również przed wydaniem postanowienia o wszczęciu śledztwa lub dochodzenia".

Wątpliwości co do możliwości umorzenia niewszczętego jeszcze postępowania były podnoszone na każdym etapie toczącego się procesu legislacyjnego. Zwróciła na to uwagę również Monika Płatek w opinii z dnia 31 stycznia $2011 \mathrm{r}$. przygotowanej na zlecenie Biura Analiz Sejmowych (Płatek 2016). Zauważyła ona, iż polskie przepisy nie przewidują możliwości umorzenia niewszczętego postępowania. Zaproponowała więc następujące brzmienie art. 62a u.p.n.: ,Jeżeli przedmiotem czynu, o którym mowa w art. 62 ust. 1 lub 3, są środki odurzające lub substancje psychotropowe na własny użytek w ilości określonej w art. 62 ust. 3 Ustawy, nie wszczyna się postępowania, a wszczęte umarza”. Nie wchodząc w szczegóły dotyczące prawidłowości rozwiązania przyjętego w nowelizacji z punktu widzenia prawa karnego procesowego, należy wyrazić przekonanie, że art. 62a u.p.n. w omawianym zakresie mógł zostać skonstruowany precyzyjniej.

Posiadanie nieznacznych ilości środków odurzających lub substancji psychotropowych, przeznaczonych na własny użytek, pozostaje czynem zabronionym pod groźbą kary. Nowelizacja wypełnia więc zobowiązania międzynarodowe, wynikające z art. 3 ust. 2 konwencji Narodów Zjednoczonych o zwalczaniu nielegalnego obrotu środkami odurzającymi i substancjami psychotropowymi (Dz. U. 1995, Nr 15, poz.69). Konwencja ta pozostawia bowiem pewien margines swobody interpretacyjnej, który przez państwa nią związane jest traktowany różnorodnie. Odnosi się to choćby do stosowania tzw. oportunizmu ścigania (Kuźmicz, Mielecka-Kubień, Stasiowski, Wiszejko-Wierzbicka 2009, 3; por. Krajewski 
1999, 10). Rozwiązanie przyjęte w art. 62a u.p.n. polega właśnie na wprowadzeniu w tzw. prawie antynarkotykowym tej instytucji, opartej m.in. na przesłance niecelowości ukarania sprawcy. Jest to więc rozwiązanie zbliżone do tzw. umorzenia absorpcyjnego, określonego w art. 11 k.p.k. Oznacza ono brak sankcji karnych w stosunku do sprawców czynów charakteryzujących się niską społeczną szkodliwością, przy zachowaniu całkowitego zakazu posiadania środków odurzających i substancji psychotropowych. Z całą pewnością nie można więc określić nowelizacji jako depenalizacji posiadania niewielkich ilości narkotyków. Tym bardziej nie można przyjętych rozwiązań określić jako dekryminalizacji lub legalizacji takiego zachowania ${ }^{5}$.

\subsection{Nowe środki o charakterze leczniczym}

Nowelizacja miała na celu umożliwienie odstępowania - w określonych sytuacjach - od ścigania sprawców drobnych przestępstw związanych z używaniem narkotyków, w stosunku do których realizacja represji karnej nie przynosiła jakichkolwiek pozytywnych efektów. Nie wpływała ona bowiem ani na zwalczanie nielegalnej podaży substancji psychoaktywnych, ani na zmniejszenie popytu. Działo się tak tym bardziej, że represji karnej wobec takich sprawców prawie nigdy nie towarzyszyło stosowanie odpowiednich środków terapeutycznych, leczniczych czy edukacyjnych. Równocześnie represja ta, poprzez stygmatyzację sprawców, stanowić mogła początek procesu wykluczania społecznego lub ich demoralizacji. Nowelizacja rozszerzyła więc katalog alternatywnych środków o charakterze leczniczym, realizujących zasadę „leczyć zamiast karać".

Nowelizacja nałożyła na prokuratora oraz sąd obowiązek zbierania informacji na temat używania przez podejrzanego/oskarżonego substancji psychoaktywnych, jeżeli zachodzi uzasadnione podejrzenie, że sprawca jest osobą uzależnioną lub używającą szkodliwie tych substancji (art. 70a u.p.n.). Informacje zbierane mają być przez specjalistów terapii uzależnień, pod kątem możliwości i celowości zastosowania alternatywnych środków leczniczych, określonych w u.p.n. Dostrzeżono, iż tego rodzaju dane nie były w ogóle w sferze zainteresowania organów wymiaru sprawiedliwości w ramach toczących się postępowań karnych, czego konsekwencją było ich niestosowanie przez prokuraturę i sąd, pomimo iż były do ich dyspozycji.

Kolejną zmianą wprowadzoną nowelizacją było rozszerzenie możliwości stosowania instytucji zawieszenia postępowania w celu poddania się

${ }^{5}$ W ocenie prok. Macieja Nowickiego (Prokuratura Rejonowa Warszawa-Praga Północ) art. 62a u.p.n. to regulacja w wielu przypadkach korzystna. Jednocześnie zauważył on, że sformułowanie tego przepisu jest wynikiem pewnego kompromisu. Mimo to - jego zdaniem - art. 62a stanowi dobry balans pomiędzy dwoma przeciwnymi sobie modelami zapobiegania narkomanii i spełnia założenia projektodawcy. Prokurator M. Nowicki wskazał również na pragmatyzm płynący z tej regulacji - możliwość umorzenia postępowania, kiedy jest ono niecelowe. 
przez podejrzanego/oskarżonego stosownemu leczeniu (art. 72 u.p.n.). Tak jak wcześniej, z możliwości tej może skorzystać osoba uzależniona lub używająca szkodliwie substancji psychoaktywnej, której zarzucono popełnienie czynu w związku z uzależnieniem, zagrożonego karą nieprzekraczającą 5 lat pozbawienia wolności. Po zakończeniu leczenia postępowanie może zostać warunkowo umorzone (uwzględniając wyniki leczenia, prokurator postanawia o ewentualnym wystąpieniu do sądu $\mathrm{z}$ wnioskiem o warunkowe umorzenie postępowania). Ustawodawca wprowadził natomiast możliwość warunkowego umorzenia postępowania, bez względu na uprzednią karalność sprawcy. Nowelizacja ustanowiła zatem wyjątek od zasady określonej w art. $66 \S 1$ k.k., ograniczającej możliwość zastosowania warunkowego umorzenia postępowania jedynie do sprawców niekaranych wcześniej za przestępstwo umyślne. W przypadku osób uzależnionych lub używających szkodliwie narkotyków jak zauważył projektodawca - postulat ten okazywał się często niemożliwy do zrealizowania (tamże, 17). Przed wejściem w życie nowelizacji nie można było bowiem zastosować wobec nich warunkowego umorzenia postępowania, co wykluczało także sens korzystania z instytucji zawieszenia postępowania $\mathrm{w}$ celu podjęcia leczenia. Zmiana ta, w połączeniu $\mathrm{z}$ ww. obowiązkiem zbierania informacji o oskarżonym (art. 70a u.p.n.), przyczynić się miała do częstszego stosowania instytucji zawieszenia postępowania karnego w celu podjęcia się przez sprawcę leczenia - a docelowo - instytucji warunkowego umorzenia postępowania karnego. Jak zauważył projektodawca, ,zastosowanie w takiej sytuacji warunkowego umorzenia postępowania pomimo wcześniejszej karalności sprawcy może więc być uzasadnione, tym bardziej że pomyślny wynik terapii stanowi w takim wypadku jednoznaczną przesłankę istnienia pozytywnej prognozy kryminologicznej" (tamże, 18).

Całkowicie nową instytucją wprowadzoną nowelizacją była możliwość udzielenia skazanemu, uzależnionemu od narkotyków oraz odbywającemu karę pozbawienia wolności za popełnienie przestępstwa w związku z uzależnieniem, przerwy w wykonywaniu kary w celu podjęcia leczenia lub rehabilitacji (art. 73a u.p.n.). Warunkiem udzielenia przerwy jest wykazanie przez skazanego, że ma zagwarantowane miejsce leczenia lub rehabilitacji w odpowiednim zakładzie opieki zdrowotnej. Ponadto, czas pozostały do odbycia kary pozbawienia wolności nie może być dłuższy niż 2 lata. Po zakończeniu leczenia lub rehabilitacji i uwzględniając ich wyniki, sąd penitencjarny może warunkowo zwolnić skazanego z odbywania reszty kary, niezależnie od tego, czy spełnione zostały przesłanki określone w art. 78 k.k. (możliwość warunkowego przedterminowego zwolnienia po odbyciu co najmniej połowy kary oraz dwóch trzecich albo trzech czwartych w warunkach tzw. recydywy).

Założeniami rzeczonej zmiany było, z jednej strony, zapewnienie lepszych warunków do odbycia leczenia lub rehabilitacji, z drugiej zaś, odciążenie $\mathrm{w}$ tym zakresie oddziałów terapeutycznych $\mathrm{w}$ jednostkach penitencjarnych. 
Ograniczenie dopuszczalności stosowania przerwy w wykonywaniu kary pozbawienia wolności poprzez wyznaczenie maksymalnej długości czasu pozostałego do odbycia kary wydaje się być ponadto korzystne dla potencjalnych beneficjentów tej instytucji. Jak wskazał bowiem projektodawca, przy skazaniu na karę do czterech lat pozbawienia wolności (która to stanowi znakomitą większość w sprawach o przestępstwa związane z używaniem środków odurzających lub substancji psychotropowych), będą oni mogli starać się o przerwę, zanim jeszcze nabędą uprawnienia do warunkowego przedterminowego zwolnienia, co może mieć pewną wartość motywującą do podjęcia takiej próby (tamże, 19).

\section{OCENA STOSOWANIA NOWELIZACJI}

\subsection{Art. 62a u.p.n.}

Punktem wyjścia do oceny stosowania art. 62a u.p.n. w ramach niniejszego opracowania jest niewątpliwie liczba skazań za przestępstwo posiadania substancji psychoaktywnych na przestrzeni lat. Ukazuje ją wykres 1.

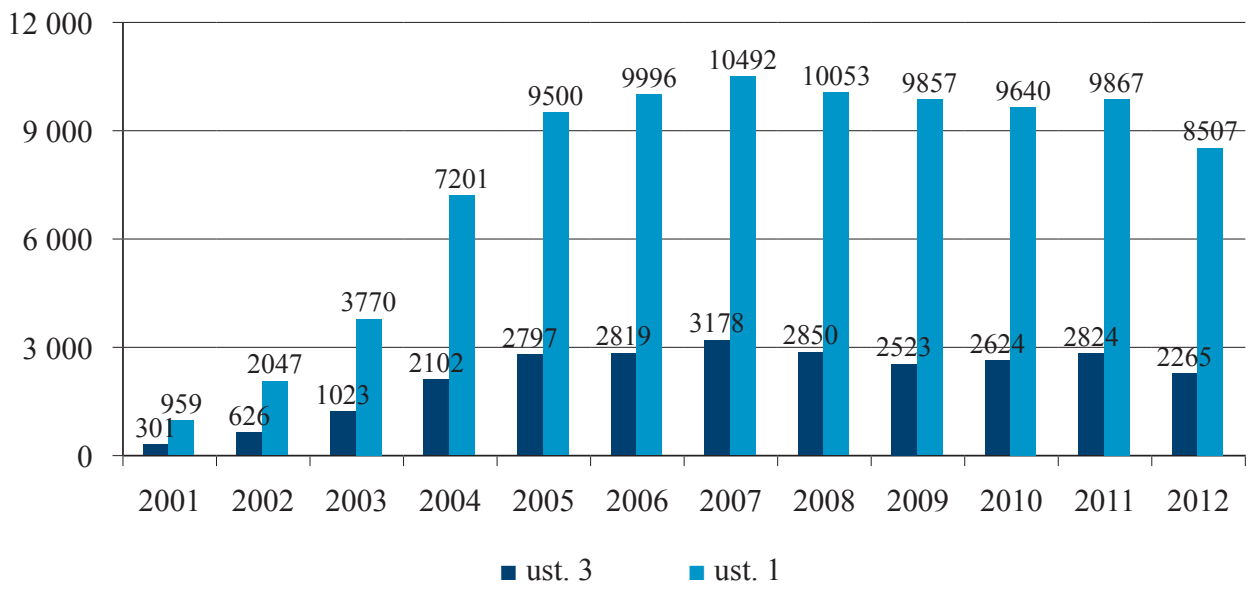

Wykres 1. Liczba osób prawomocnie skazanych na podstawie art. 62 u.p.n.

Źródło: dane statystyczne Ministerstwa Sprawiedliwości

Liczbę spraw umorzonych przez prokuraturę na podstawie art. 62a przedstawiają natomiast wykresy 2 i 3 . 
Nowelizacja ustawy o przeciwdziałaniu narkomanii w trzy lata po jej wejściu w życie... 125

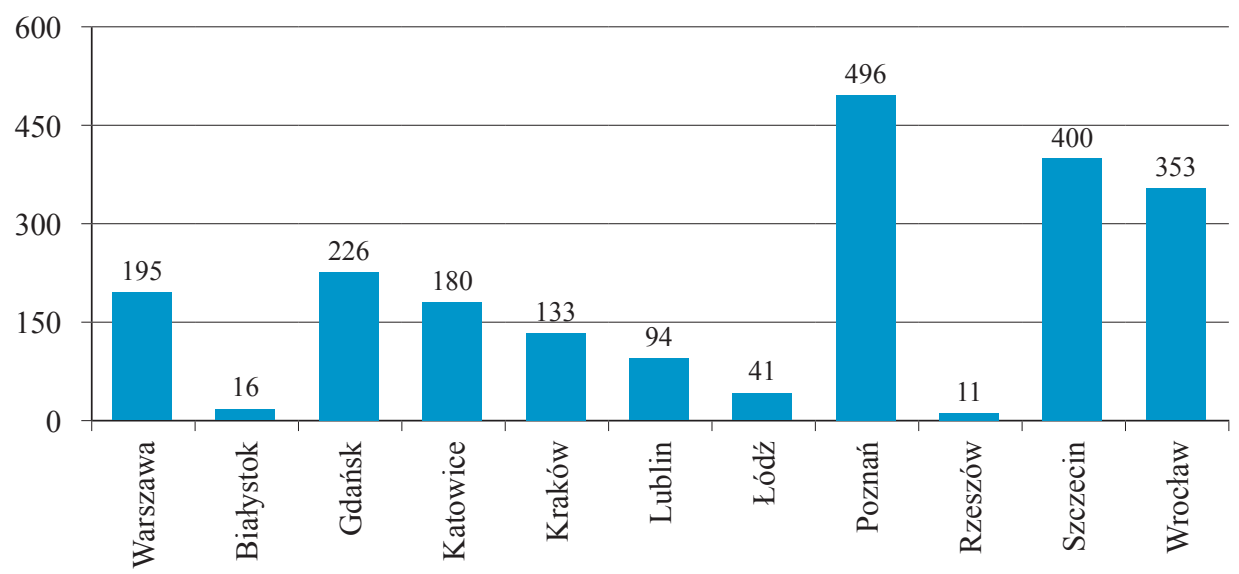

Wykres 2. Liczba spraw umorzonych przez Prokuraturę na podstawie art. 62 u.p.n. wg apelacji w roku 2012

Źródło: Kładoczny, Wilamowska, Kubaszewski P. (red.) 2013, 102.

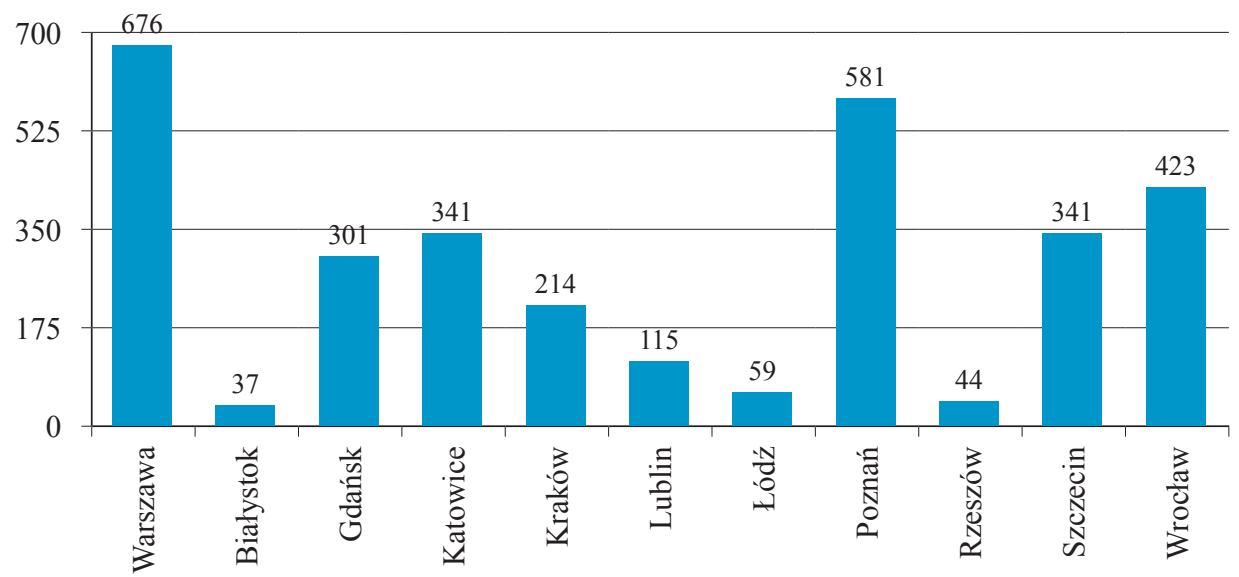

Wykres 3. Liczba spraw umorzonych przez prokuraturę na podstawie art. 62 u.p.n. wg apelacji w roku 2013

Źródło: dane statystyczne Ministerstwa Sprawiedliwości.

Wykres 1 wskazuje, iż - do momentu wejścia w życie nowelizacji ${ }^{6}$ - ponad 13 tysięcy osób było każdego roku skazywanych za posiadanie narkotyków w typie podstawowym (ust. 1) oraz typie uprzywilejowanym (ust. 3) tego

\footnotetext{
${ }^{6}$ Nowelizacja weszła w życie 9 grudnia 2011 r., zatem dopiero dane za 2012 r. obrazują nowy stan prawny.
} 
przestępstwa. W 2012 roku - a więc już w nowym stanie prawnym - liczba ta spadła do 10772 skazań. Wartości te należy zestawić z liczbą spraw umorzonych przez prokuraturę na podstawie art. 62a u.p.n. Intencje projektodawcy wyrażone $\mathrm{w}$ uzasadnieniu nowelizacji oraz w samym sformułowaniu art. $62 \mathrm{a}^{7}$ wskazują, że umorzenia spraw o posiadanie nieznacznych ilości substancji psychoaktywnych posiadanych na własny użytek powinny następować jak najszybciej - a więc przede wszystkim na etapie postępowania przygotowawczego. Zgodnie z danymi zawartymi na wykresach 2 i 3 , na podstawie art. 62a u.p.n. prokuratorzy umorzyli 2145 spraw w 2012 r. oraz $3132 \mathrm{w}$ roku $2013^{8}$. Drugi rok obowiązywania nowej ustawy przyniósł więc wzrost liczby umorzeń o niemal 1000 przypadków, co trzeba ocenić zdecydowanie pozytywnie ${ }^{9}$. Już jednak na tym etapie rozważań należy postawić tezę, że ich liczba - w zestawieniu z pozostałą roczną liczbą skazań za przestępstwo posiadania narkotyków na poziomie prawie 11 tysięcy - jest wciąż zbyt mała.

Niezwykle interesująca jest ponadto analiza liczby umorzeń w ramach poszczególnych apelacji. Zarówno w pierwszym, jak i w drugim roku obowiązywania nowelizacji najsłabiej wypadają apelacje białostocka oraz rzeszowska. Można by nawet zaryzykować tezę, że na wschodzie Polski nowelizacja nie znalazła zastosowania w należytym stopniu. Co prawda, jak ocenia K. Krajewski, używanie narkotyków jest wszędzie na świecie zjawiskiem o jednoznacznie miejskim, a nawet wielkomiejskim charakterze (Krajewski 2008c, 8). Nie wydaje się jednak, aby aż tak znacząca różnica w liczbie umorzeń mogła być uzasadniona mniejszą liczbą tego rodzaju spraw na wschodzie kraju. Przykładowo, 11 umorzeń w apelacji rzeszowskiej w 2012 r. to niecałe 1 umorzenie na miesiąc na obszarze odpowiadającym mniej więcej obszarowi województwa. Nie wydaje się zatem możliwe, aby na taki teren przypadała średnio mniej niż 1 sprawa o posiadanie niewielkiej ilości narkotyków (przeznaczonych na własny użytek sprawcy) miesięcznie. $Z$ drugiej strony, warto wskazać na niewielką liczbę umorzeń w apelacjach obejmujących dwie wielkie aglomeracje - Warszawę i Łódź. Apelacja warszawska zanotowała co prawda znaczny wzrost liczby umorzeń w roku 2013, jak się jednak wydaje,

7 Jak już wskazano, art. 62a u.p.n. stanowi, iż ,postępowanie można umorzyć również przed wydaniem postanowienia o wszczęciu śledztwa lub dochodzenia”.

${ }^{8}$ Zgodnie z danymi otrzymanymi od komisarza Michała Witkowskiego (Biuro Służby Kryminalnej KGP), w 2013 r., na 22599 zakończonych postępowań przygotowawczych w sprawach o czyny z art. 62 ust. 1 oraz 62 ust. 3 u.p.n., Policja wnosiła o umorzenie postępowania na podstawie art. 62a u.p.n. 1877 razy. Komenda Główna Policji nie dysponuje jednak danymi na temat dalszego losu tych wniosków. Nie wiadomo zatem, ile spośród nich zostało pozytywnie rozpatrzonych przez prokuraturę.

${ }^{9} \mathrm{Na}$ wzrost ten wskazała także Barbara Wilamowska - Koordynator Ministra Sprawiedliwości ds. Krajowego Programu Przeciwdziałania Narkomanii. Jej zdaniem, zespół przygotowujący nowelizację nie spodziewał się od razu wielkich efektów. Jak zauważyła, potrzebna jest najpierw praca edukacyjna, jak np. szkolenia prokuratorów. Członkowie zespołu - w jej opinii - zostali jednak pozytywnie zaskoczeni działaniem prokuratur i sądów. 
liczba wszystkich spraw o czyny z art. 62 ust. 1 oraz 62 ust. 3 u.p.n. jest w niej znacznie większa niż $w$ innych apelacjach. Warto również wspomnieć, że autorzy projektu, jeszcze przed wejściem w życie nowelizacji, przeprowadzili szereg spotkań z prokuratorami i sędziami apelacji poznańskiej, szczecińskiej i wrocławskiej. Nie dziwi zatem, że od samego początku obowiązywania nowelizacji akurat te trzy apelacje przodują w liczbie umorzeń drobnych spraw związanych z posiadaniem narkotyków.

Rok 2014 przyniósł kolejny wzrost liczby umorzeń na etapie postępowania przygotowawczego - do 4273 przypadków, co przedstawia wykres 4. Różnice pomiędzy poszczególnymi apelacjami pozostały jednak na bardzo zbliżonym poziomie. Ponadto, najwięcej umorzeń na podstawie art. 62a u.p.n. w 2014 r. miało miejsce w apelacji poznańskiej, a nie największej - apelacji warszawskiej.

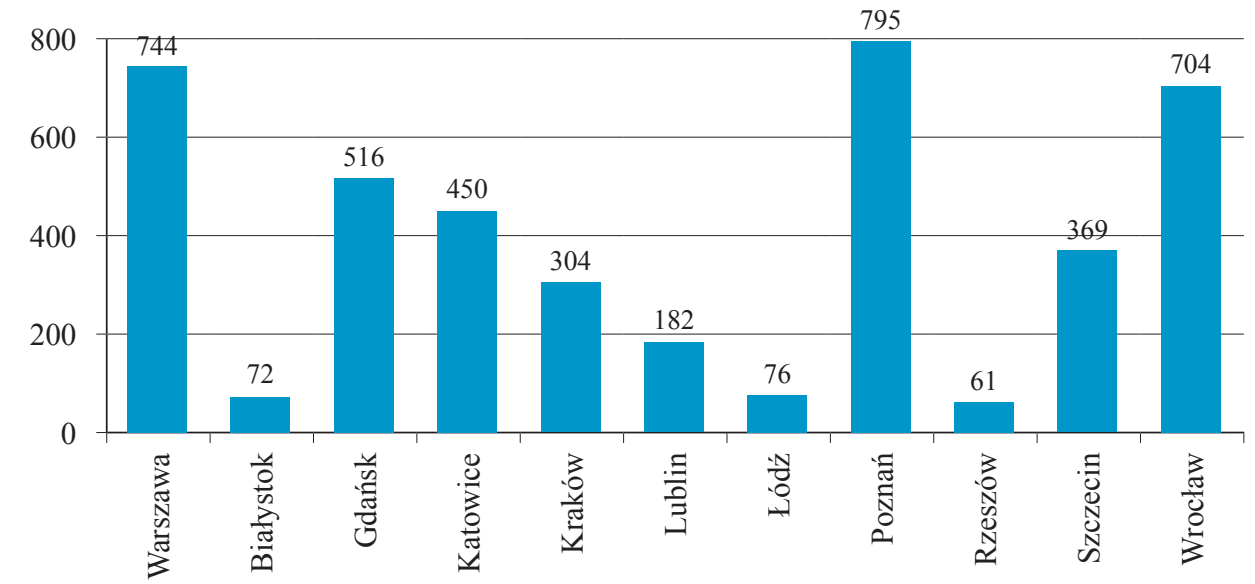

${ }^{a}$ Przedstawione dane nie znalazły się w pierwotnej wersji raportu, który został opublikowany 9 grudnia $2014 \mathrm{r}$.

Wykres 4. Liczba spraw umorzonych przez prokuraturę na podstawie art. 62a u.p.n. wg apelacji w roku $2014^{a}$

Źródło: Prokurator Generalny. Sprawozdanie Prokuratora Generalnego z rocznej działalności prokuratury w $2014 \mathrm{r}$. www.pg.gov.pl [dostęp 31.07.2015]

Następnie należy przeanalizować, co dzieje się ze sprawami o posiadanie narkotyków na etapie postępowania sądowego ${ }^{10}$.

${ }^{10}$ Barbara Wilamowska oceniła, że liczba umorzeń i warunkowych umorzeń spraw o posiadanie narkotyków na etapie postępowania sądowego wzrosła o 200\%. Nastąpiła także zmiana samej struktury orzekanych kar, mająca przejawiać się częstszym stosowaniem kar wolnościowych i środków karnych. Ponadto, w opinii B. Wilamowskiej, sądy korygują działania prokuratur w tym zakresie. 
Dane dotyczące osądzonych za przestępstwo posiadania narkotyków w sądach rejonowych przedstawiają tabele 1, 2 i 3. Podkreślenia wymaga fakt, iż dane te dotyczą skazań nieprawomocnych, będą zatem delikatnie różnić się od tych przedstawionych na wykresie 1 . Jak zauważył jednak K. Krajewski, w sprawach o posiadanie narkotyków niezwykle rzadko ma miejsce składanie środków odwoławczych (Krajewski 2008c, 38). W badanej przez niego próbie (przebadane zostały 102 sprawy z art. 62 u.p.n.), apelację wniósł tylko jeden skazany, a wyrok sądu pierwszej instancji został przez sąd apelacyjny utrzymany w mocy. Dane dotyczące nieprawomocnych skazań mogą zatem z powodzeniem stanowić statystyczny obraz spraw o posiadanie narkotyków ${ }^{11}$.

Tabela 1

\begin{tabular}{|c|c|c|c|c|c|}
\hline \multirow[b]{2}{*}{ Osądzeni } & \multirow[b]{2}{*}{ Skazani } & \multicolumn{2}{|c|}{ Pozbawienie wolności } & \multirow{2}{*}{$\begin{array}{l}\text { Ograniczenie } \\
\text { wolności }\end{array}$} & \multirow{2}{*}{$\begin{array}{l}\text { Grzywna } \\
\text { samoistna }\end{array}$} \\
\hline & & razem & $\begin{array}{c}\text { z warunkowym } \\
\text { zawieszeniem }\end{array}$ & & \\
\hline \multicolumn{6}{|c|}{$2009 \mathrm{r}}$. \\
\hline 10699 & 9777 & 6610 & 5967 & 1197 & 1969 \\
\hline \multicolumn{6}{|c|}{$2010 \mathrm{r}$. } \\
\hline 12050 & 10658 & 6798 & 6131 & 1463 & 2397 \\
\hline \multicolumn{6}{|c|}{$2011 \mathrm{r}}$. \\
\hline 14334 & 12451 & 7478 & 6697 & 1843 & 3127 \\
\hline \multicolumn{6}{|c|}{$2012 \mathrm{r}$. } \\
\hline 13456 & 10915 & 6368 & 5703 & 1645 & 2891 \\
\hline \multicolumn{6}{|c|}{2013 r. } \\
\hline 12812 & 10503 & 5974 & 5351 & 1707 & 2821 \\
\hline
\end{tabular}

Źródło: dane statystyczne Ministerstwa Sprawiedliwości.

Dane zawarte w tabeli 1 wskazują, że nowelizacja przyniosła niewielkie zmiany w samej idei karania sprawców za przestępstwo posiadania narkotyków na etapie postępowania sądowego. Liczba skazanych w 2012 i 2013 r. jest wyraźnie mniejsza niż w roku 2011, co jest spowodowane m.in. większą liczbą osądzonych spraw w 2011 r. Istotna jest zatem różnica pomiędzy liczbą

${ }^{11}$ W tym kontekście należy raz jeszcze podkreślić, iż niniejszy raport został sporządzony na podstawie wszelkich dostępnych w tej chwili danych statystycznych. Ministerstwo Sprawiedliwości - w sprawach o posiadanie narkotyków - nie dysponuje analogicznymi danymi dla wyroków prawomocnych. 
osądzonych spraw a liczbą skazań (różnica ta zwana dalej: liczbą nie-skazanych), która na przestrzeni lat 2009-2013 wynosi: 2009 r. - 922, 2010 r. - 1392, 2011 r. - 1883, 2012 r. - 2541 oraz 2013 r. - 2309 spraw. Następnie należy zestawić liczbę nie-skazanych z liczbą osądzonych spraw w danym roku. Takie zestawienie wskazuje, że liczba nie-skazanych w latach 20092013 stanowi odpowiednio: $8,62 \% ; 11,55 \% ; 13,14 \% ; 18,88 \%$ oraz $18,02 \%$ wszystkich osądzonych spraw. Na przestrzeni lat widoczny jest zatem wzrost liczby nie-skazanych, który jedynie do 2011 r. da się wytłumaczyć ogólnym zwiększeniem liczby spraw rozpoznawanych przez sądy. Od 2012 r. - a więc od wejścia w życie nowelizacji - nastąpiło bowiem zmniejszenie liczby osądzonych spraw, a mimo to procentowa liczba nie-skazanych zwiększyła się i utrzymuje się na poziomie ponad 18\%. Nie wydaje się jednak, aby wartość tę można było uznać za wystarczającą i spełniającą oczekiwania projektodawcy wobec nowelizacji.

Warto zastanowić się również nad przyczyną zmniejszenia liczby wszystkich spraw rozpoznanych przez sądy. Jeżeli taki stan rzeczy wynika z samego faktu wejścia w życie nowelizacji, jest to jej niewątpliwy sukces.

Analiza samej struktury orzekanych kar nie pozwala natomiast na stwierdzenie jakiejś znaczącej zmiany w tej kwestii po wejściu w życie nowelizacji.

Tabela 2

\begin{tabular}{|c|c|c|c|c|}
\hline \multirow{2}{*}{$\begin{array}{c}\text { Orzeczono } \\
\text { wyłącznie środek } \\
\text { karny }\end{array}$} & \multirow{2}{*}{$\begin{array}{c}\text { Warunkowe } \\
\text { umorzenie } \\
\text { postępowania }\end{array}$} & \multicolumn{3}{|c|}{ Umorzenie postępowania } \\
\hline & & razem & $\begin{array}{l}\text { na podstawie } \\
\text { art. } 62 \mathrm{a} \text { u.p.n. }\end{array}$ & $\begin{array}{c}\text { na podstawie } \\
\text { art. } 17 \S 1 \text { pkt } 3 \text { k.p.k. }\end{array}$ \\
\hline \multicolumn{5}{|c|}{2009 r. } \\
\hline- & 669 & 159 & - & b.d. \\
\hline \multicolumn{5}{|c|}{$2010 \mathrm{r}}$. \\
\hline- & 1068 & 185 & - & b.d. \\
\hline \multicolumn{5}{|c|}{$2011 \mathrm{r}}$. \\
\hline 2 & 1575 & 212 & - & b.d. \\
\hline \multicolumn{5}{|c|}{2012 r. } \\
\hline 1 & 1833 & 609 & 160 & 256 \\
\hline \multicolumn{5}{|c|}{$2013 \mathrm{r}}$. \\
\hline b.d. & 1781 & 451 & 208 & 135 \\
\hline
\end{tabular}

Źródło: dane statystyczne Ministerstwa Sprawiedliwości. 
Dane wynikające z tabeli 2 są konsekwencją tych zawartych w tabeli 1. Powyższa tabela stanowi bowiem uszczegółowienie pozycji „nie-skazani”, o której była już mowa.

Na przestrzeni lat widoczny jest wzrost liczby warunkowych umorzeń postępowania, który tylko do 2011 r. da się wytłumaczyć ogólnym zwiększeniem liczby spraw rozpoznawanych przez sądy. Taki stan rzeczy wynikać może z samego faktu wejścia w życie nowelizacji, co stanowiłoby jej niewątpliwy sukces. Analogiczna teza dotyczy także umorzeń postępowania. Przyczyn spadku liczby umorzeń i warunkowych umorzeń postępowania w 2013 r. względem roku 2012 upatrywać należy w mniejszej liczbie wszystkich osądzonych wówczas spraw. Dalej jednak widoczny jest wyraźny wzrost umorzeń i warunkowych umorzeń w stosunku do lat poprzednich, a ich „częstotliwość” w kontekście wszystkich spraw rozpoznanych przez sądy, od momentu wejścia w życie nowelizacji, utrzymuje się na stałym poziomie.

Z ogólnej kategorii postępowań umorzonych przez sądy wydzielone zostały umorzenia na podstawie art. $17 \S 1$ pkt 3 k.p.k. ${ }^{12}$ (znikoma społeczna szkodliwość czynu) oraz - co szczególnie istotne dla niniejszego opracowania - art. 62a u.p.n. Zgodnie z przedstawionymi danymi, w 2012 r. umorzenia z art. 62a stanowiły $26,27 \%$ wszystkich umorzeń spraw o posiadanie narkotyków, natomiast te oparte o przesłankę znikomej społecznej szkodliwości czynu - 42,04\%. W kolejnym roku proporcje te się odwróciły - wynosiły odpowiednio 46,12\% (umorzenia na podstawie art. 62a u.p.n.) i 29,93\% (umorzenia na podstawie art. $17 \S 1$ pkt 3 k.p.k.).

Analizując przedstawione dane, należy jednak stwierdzić, że liczba umorzeń spraw o posiadanie narkotyków, w tym umorzeń na podstawie art. 62a u.p.n. najważniejszej zmiany nowelizacji - na etapie postępowania sądowego (tak jak i na etapie postępowania przygotowawczego) jest wciąż zbyt mała. Sto sześćdziesiąt umorzonych spraw na podstawie tego przepisu w 2012 r. stanowi zaledwie $1,19 \%$ wszystkich postępowań przeprowadzonych przez sądy o czyn z art. 62 u.p.n. W 2013 r. odsetek ten wyniósł 1,62\%. Z całą pewnością więc, art. 62a u.p.n. nie stał się skutecznym narzędziem do wyraźnego zmniejszenia liczby skazań za przestępstwo posiadania narkotyków, tak jak życzył sobie tego projektodawca. Jedną z przyczyn takiego stanu rzeczy obrazuje tabela 3.

${ }_{12}$ Prokurator Maciej Nowicki wskazał na praktyczne trudności związane z umarzaniem przez prokuratorów postępowań na podstawie art. $17 \S 1$ pkt 3 k.p.k. Wszystkie te umorzenia są bowiem objęte kontrolą w nadzorze służbowym. Artykuł 62a u.p.n., stanowiący odrębną przesłankę umorzenia postępowania o posiadanie nieznacznych ilości narkotyków przeznaczonych na własny użytek sprawcy, jest zatem wygodniejszy w stosowaniu w ramach hierarchicznej struktury prokuratury. Jak dotąd, w Prokuraturze Rejonowej Warszawa-Praga Północ nie została przeprowadzona kontrola umorzeń na podstawie art. 62a u.p.n., co - w ocenie rozmówcy - wskazuje, że przepis ten nie budzi kontrowersji. W opinii prok. Nowickiego, rzeczona podstawa do umorzenia postępowania jest na tyle specyficzna, że trudno kwestionować poszczególne decyzje o umorzeniu. 
Nowelizacja ustawy o przeciwdziałaniu narkomanii w trzy lata po jej wejściu w życie... 131

Tabela 3

\begin{tabular}{|c|c|c|c|}
\hline \multirow{2}{*}{$\begin{array}{c}\text { Odstąpienie od } \\
\text { wymierzenia kary }\end{array}$} & \multirow{2}{*}{$\begin{array}{c}\text { Nadzwyczajne } \\
\text { złagodzenie kary }\end{array}$} & $\begin{array}{c}\text { Skazanie w wyniku uwzględnienia wniosku } \\
\text { z artykułów: }\end{array}$ \\
\cline { 3 - 5 } & \multicolumn{5}{|c|}{ Art. 335 § 1 k.p.k. } & Art. 387 § 1 k.p.k. \\
\hline \multicolumn{5}{|c|}{2012 r. } \\
\hline 8 & 200 & 5273 & 1182 \\
\hline \multicolumn{5}{|c|}{2013 r. } \\
\hline 13 & 282 & 5000 & 1236 \\
\hline
\end{tabular}

Źródło: dane statystyczne Ministerstwa Sprawiedliwości.

Zarówno w 2012, jak i 2013 roku, ponad 59\% (dokładnie: 59,14\% w 2012 r. i 59,37\% w 2013 r.) spośród wszystkich skazań za posiadanie substancji psychoaktywnych odbyło się w ramach tzw. konsensualnych form zakończenia postępowania. O ile zatem, powtarzając za prok. Maciejem Nowickim, stosowanie art. 62a u.p.n. nie powinno stanowić negatywnej przesłanki przy ocenie służbowej, tak - w ocenie autora niniejszego raportu - zakończenie postępowania (a tym bardziej wielu postępowań) wyrokiem skazującym może stanowić przesłankę pozytywną. Tyczy się to zarówno prokuratorów, jak i sędziów.

W tym kontekście stosowne wydaje się wspomnienie o badaniach aktowych, przeprowadzonych przez autora niniejszego raportu w maju 2011 r. - a więc jeszcze przed wejściem w życie nowelizacji. Badania, którymi objęto 18 losowo wybranych spraw z dwóch sądów rejonowych w Warszawie (SR dla Warszawy-Mokotowa oraz SR dla Warszawy-Pragi Północ), zawierają szczegółową analizę spraw sądowych dotyczących popełnienia czynu określonego w art. 62 u.p.n.

Zgodnie z przeprowadzonymi badaniami, każde z orzeczeń o wymierzeniu przez sąd kary pozbawienia wolności zapadło w trybie art. 335 k.p.k. - tzw. skazania bez rozprawy. Były to zarazem jedyne przypadki zastosowania tej kary (stanowiły one 17,65\% wszystkich spraw). Co jednak szczególnie istotne, akta 10 na 14 postępowań, które nie zakończyły się w tym trybie, zawierały wnioski podejrzanych o skazanie bez rozprawy ${ }^{13}$. Można więc zastanowić się nad postawieniem tezy, czy czynności prokuratora w sprawach dotyczących posiadania narkotyków nie sprowadzają się w zasadzie do „podsunięcia” podejrzanemu do podpisu wniosku o tzw. skazanie bez rozprawy, zawierającego niewspółmiernie surową karę pozbawienia

${ }^{13}$ Ponadto, w jednej z czterech spraw, które nie zakończyły się tzw. skazaniem bez rozprawy, podejrzany odmówił podpisania wniosku z art. 335 k.p.k. podczas pierwszego przesłuchania. Chciał, aby sprawa trafiła do sądu, ponieważ - jego zdaniem - proponowana przez prokuratora kara pozbawienia wolności z warunkowym zawieszeniem jej wykonania, grzywny oraz dozoru kuratora - była zbyt surowa. W kolejnej ze spraw, sprawca wycofał wniosek już podczas posiedzenia w przedmiocie jego rozpoznania. 
wolności z warunkowym zawieszeniem jej wykonania. Takim działaniom prokuratury sprzyja również bardzo rzadki udział obrońców ${ }^{14} \mathrm{w}$ sprawach $\mathrm{z}$ art. 62 u.p.n.

Sposób doboru spraw oraz rozmiar badanej próby nie upoważniają do nadania przedstawionym badaniom cech reprezentatywności, zwłaszcza $\mathrm{w}$ skali krajowej. Niemniej, należy zwrócić uwagę na pewne niebezpieczeństwo, jakie niesie ze sobą zbyt automatyczne korzystanie $\mathrm{z}$ form konsensualnych przez organy wymiaru sprawiedliwości. Jeżeli bowiem oskarżyciel publiczny podejmować ma wszelkie działania zmierzające do jak najszybszego ukarania sprawcy jak najsurowszym wyrokiem, to działania te są nie do pogodzenia z zasadą prawdy materialnej (art. 2 § 2 k.p.k.) - zasadą o charakterze nadrzędnym, której podporządkowane są inne zasady procesu karnego.

Tabela $4^{a}$

\begin{tabular}{|l|c|}
\hline \multicolumn{1}{|c|}{ Apelacja } & $\begin{array}{c}\text { Umorzenie postępowania } \\
\text { na podstawie art. 62a u.p.n. }\end{array}$ \\
\hline Białystok & 1 \\
\hline Gdańsk & 25 \\
\hline Katowice & 12 \\
\hline Kraków & 9 \\
\hline Lublin & 11 \\
\hline Łódź & 3 \\
\hline Poznań & 4 \\
\hline Rzeszów & 1 \\
\hline Szczecin & 0 \\
\hline Warszawa & 109 \\
\hline Wrocław & 34 \\
\hline
\end{tabular}

a Tabela zawiera 208 przypadków umorzeń na podstawie art. 62a u.p.n. oraz jeden przypadek umorzenia postępowania na podstawie art. $17 \S 1$ pkt 3 k.p.k. Dane statystyczne nie precyzują jednak, $\mathrm{w}$ ramach której apelacji nastąpiło to jedno umorzenie.

Źródło: dane statystyczne Ministerstwa Sprawiedliwości.

Przeprowadzone badania wykazały zatem nadmierne, automatyczne stosowanie instytucji tzw. skazania bez rozprawy. Przy ocenie praktycznego stosowania instytucji wprowadzonych nowelizacją przez organy wymiaru sprawiedliwo-

14 W ramach badań odnotowano udział obrońców zaledwie w dwóch sprawach. W jednym postępowaniu uczestniczyło dwóch obrońców z wyboru, w drugim zaś - obrońca z urzędu. 
ści należy zatem stwierdzić, iż wyżej wymieniony trend jest sprzeczny z duchem nowej u.p.n. Konsensualne formy zakończenia postępowania stanowią ponad połowę skazań za przestępstwo posiadania narkotyków, są więc zarazem największą „przeszkodą" do zrealizowania celów, jakie autorzy projektu pokładali w nowelizacji - odstąpienia od ścigania najdrobniejszych przestępstw polegających na posiadaniu substancji psychoaktywnych.

Charakterystyczne jest także rozłożenie sądowych umorzeń postępowania w trybie art. 62a u.p.n. w ramach poszczególnych apelacji. Dane dotyczące osądzonych za przestępstwo posiadania narkotyków na podstawie art. 62a u.p.n. w 2013 r. w sądach rejonowych przedstawia tabela 4.

Powyższe dane wzmacniają przekonanie, że art. 62a u.p.n. nie stał się skutecznym narzędziem do wyraźnego zmniejszenia liczby skazań za przestępstwo posiadania narkotyków. Ponad połowa umorzeń na etapie postępowania sądowego pochodzi z apelacji warszawskiej - gdzie należy spodziewać się największej liczby tego rodzaju spraw. Pozostałe przypadki sądowych umorzeń postępowań na podstawie wskazanego przepisu mają charakter jedynie incydentalny ${ }^{15}$.

\subsection{Obrońca z urzędu w sprawach o posiadanie narkotyków}

Jak zostało już zauważone, częstemu stosowaniu form konsensualnych oraz niezwykle rzadkiemu składaniu środków odwoławczych w sprawach o posiadanie substancji psychoaktywnych sprzyja rzadki udział obrońców w tych sprawach. Na potrzeby niniejszego opracowania, HFPC zwróciła się zatem do 11 losowo wybranych sądów rejonowych z wnioskiem o udostępnienie informacji publicznej w zakresie:

- liczby osądzonych osób z art. 62 oraz art. 62a u.p.n. w latach 2010-2013;

- liczby przypadków, w których w ww. sprawach oskarżonemu przyznany został obrońca z urzędu.

Otrzymane dane prezentuje tabela 5.

${ }^{15}$ Adwokat Paweł Osik zaznaczył, iż zdarzają się przypadki, kiedy prokurator lub sąd sięgają do art. 62a u.p.n. W jego ocenie dzieje się to jednak niedostatecznie często. Jako przykład mec. Osik wymienił sprawę przed SR w W., w której sąd nie uwzględnił wniosku o umorzenie postępowania wobec młodego człowieka (ur. 1990 r.) o posiadanie 1,41 g marihuany. Sprawca ten został wcześniej skazany za posiadanie i udzielenie marihuany na karę łączną 1 roku pozbawienia wolności z warunkowym zawieszeniem jej wykonania na okres 3 lat próby. Kolejny czyn został popełniony w okresie próby. Sąd skazał jego klienta, wymierzając mu karę 4 miesięcy ograniczenia wolności (wobec współoskarżonego kolegi sąd od razu umorzył postępowanie na podstawie art. 62a). Dopiero na skutek apelacji, sąd okręgowy umorzył postępowanie karne na podstawie 62a u.p.n. Jednocześnie adw. Paweł Osik zauważył, iż nie spotkał w praktyce zastosowania pozostałych instytucji wprowadzonych nowelizacją (środków o charakterze leczniczym). 
Tabela 5

\begin{tabular}{|l|c|c|}
\hline \multicolumn{1}{|c|}{ Sąd } & Liczba osądzonych & $\begin{array}{c}\text { Ile razy ustanowiono/ } \\
\text { przyznano obrońcę z urzędu }\end{array}$ \\
\hline SR w Białymstoku & 550 & 83 \\
\hline SR Katowice-Zachód & 300 & 33 \\
\hline SR w Kielcach & 656 & 60 \\
\hline SR w Koszalinie & 398 & b.d. \\
\hline SR Lublin-Zachód & 965 & 216 \\
\hline SR w Lomży & 292 & b.d. \\
\hline SR w Radomiu & 609 & 30 \\
\hline SR w Rybniku & b.d. & b.d. \\
\hline SR w Słupsku & 590 & 97 \\
\hline SR w Suwałkach & 166 & b.d. \\
\hline SR dla Warszawy-Żoliborza & 428 & 9 \\
\hline
\end{tabular}

Źródło: dane z sądów rejonowych uwzględnionych w tabeli.

Z przedstawionych danych wynika, że wyznaczanie przez sąd obrońcy $\mathrm{z}$ urzędu w sprawach o posiadanie narkotyków pozostaje raczej rzadkością.

\subsection{Nowe środki o charakterze leczniczym}

Zgodnie z danymi udostępnionymi przez Prokuraturę Generalną, prokuratorzy w 2012 r. w 3 sprawach, a w pierwszym półroczu 2013 r. w 4 sprawach, zdecydowali o zawieszeniu postępowania na podstawie art. 72 u.p.n. Nie ma więc żadnych wątpliwości, że regulacja ta - nawet po wejściu w życie nowelizacji - znajduje zastosowanie jedynie incydentalnie.

W pierwszym półroczu 2013 r. prokuratorzy zarządzili zebranie informacji na temat używania przez podejrzanego substancji psychoaktywnych w trybie art. 70a u.p.n. wobec 1049 osób. Dla porównania, w tym samym okresie, na etapie postępowania przygotowawczego, zostały umorzone 1462 sprawy na podstawie art. 62a u.p.n. Można zatem zastanowić się, czy aby znacząca część umorzonych spraw nie dotyczy jedynie sprawców uzależnionych lub używających szkodliwie substancji psychoaktywnych ${ }^{16}$.

16 Taki stan rzeczy potwierdzałaby teza Barbary Wilamowskiej na temat tabeli wartości granicznych, która - w jej opinii - ograniczyłaby możliwość umarzania postępowań o posiadanie narkotyków wobec osób uzależnionych. 
Nowelizacja ustawy o przeciwdziałaniu narkomanii w trzy lata po jej wejściu w życie... 135

\section{TABELA WARTOŚCI GRANICZNYCH ${ }^{17}$}

Potrzeba opracowania wewnętrznych wytycznych (skierowanych przede wszystkim do organów prokuratury), precyzujących pojęcie „nieznacznej ilości” środka odurzającego lub substancji psychotropowej poprzez wskazanie stosownych wartości granicznych, została dostrzeżona przez samego projektodawcę. Co więcej, w uzasadnieniu nowelizacji zauważono, że taka praktyka jest stosowana w wielu krajach europejskich (Sejm VI kadencji. Uzasadnienie..., 13).

W ocenie Barbary Wilamowskiej, stworzenie tabeli wartości granicznych byłoby ze szkodą dla osób uzależnionych od narkotyków ${ }^{18}$. Należy jednak podkreślić, że ograniczenie stosowania art. 62a u.p.n. przede wszystkim do osób uzależnionych nie odzwierciedla w pełni celu wprowadzenia nowelizacji, określonego przez projektodawcę m.in. jako: ,zniwelowanie negatywnych skutków niepokojąco wzrastającej kryminalizacji osób uzależnionych i zażywajacych środki odurzajace” (Sejm VI kadencji. Cel wprowadzenia..., 22-23). Uzasadnienie, wskazując ponadto podmioty, na które miała oddziaływać nowelizacja, wyróżniło zarówno osoby fizyczne będące sprawcami przestępstw stypizowanych w u.p.n., jak i osoby fizyczne uzależnione lub używające substancji psychoaktywnych szkodliwie (Sejm VI kadencji. Uzasadnienie..., 24). Wreszcie, projektodawca wskazał, że grupa osób, która spełnia kryteria do umorzenia postępowania na podstawie art. 62a u.p.n., ,to głównie osoby młode, które eksperymentują z substancjami odurzającymi" (tamże, 28). Znajduje to swoje odzwierciedlenie także w wykładni literalnej art. 62a u.p.n., który nie ogranicza płynących z niego korzyści jedynie

17 Za wprowadzeniem tabeli wartości granicznych wyraźnie opowiedział się komisarz M. Witkowski z Komendy Głównej Policji. Jego zdaniem, zdefiniowanie konkretnej ilości dla każdego narkotyku jest niezbędne i powinno nastąpić na poziomie ustawy, najlepiej u.p.n.

Zalety płynące z wprowadzenia stosownej tabeli wartości granicznych dostrzegł także prokurator M. Nowicki. Zauważył on, że dla części prokuratorów jest oczywiste, w jakich przypadkach należy stosować art. 62a u.p.n. $Z$ drugiej jednak strony - w jego ocenie - tabela rozstrzygnęłaby wątpliwości i wprowadziłaby równość w stosowaniu tego przepisu w różnych częściach kraju. Jak zauważył rozmówca, prokuratorzy będą zawsze podchodzić do możliwości umorzenia postępowania z większą ostrożnością, jeżeli podstawa prawna nie będzie sformułowana wystarczająco jasno.

18 Osoby uzależnione potrzebują więcej substancji psychoaktywnej ,na własny użytek” niż osoby używające narkotyków rekreacyjnie. Barbara Wilamowska wyraziła zatem obawę, że ilość posiadanej substancji przez osobę uzależnioną, przeznaczonej na jej własny użytek, nie mieściłaby się w przyjętych wartościach. Jej zdaniem, tabela wartości granicznych ograniczałaby możliwość umarzania postępowań o posiadanie narkotyków wobec osób uzależnionych. Tymczasem obecnie postępowanie może zostać umorzone w oparciu o opinię specjalisty terapii uzależnień, powoływanego na podstawie art. 70a u.p.n. W opinii B. Wilamowskiej, jeżeli umarzane będą postępowania w sprawach osób uzależnionych, tym bardziej umarzane będą postępowania prowadzone przeciwko okazjonalnym użytkownikom. Ponadto, Barbara Wilamowska przewiduje, że tabela wartości granicznych spowodowałaby wzrost liczby użytkowników. Tymczasem, w opinii prawniczki Ministerstwa Sprawiedliwości, w Polsce nie dysponujemy środkami na ich terapię oraz profilaktykę. 
do osób uzależnionych lub używających szkodliwie substancji psychoaktywnych (jak ma to miejsce w przypadku art. 72 oraz 73a u.p.n.), a kierowany jest do wszystkich sprawców czynu polegającego na posiadaniu narkotyków. W tym kontekście należy również odnieść się do tezy B. Wilamowskiej, że jeżeli umarzane będą postępowania w sprawach osób uzależnionych, tym bardziej umarzane będą postępowania prowadzone przeciwko okazjonalnym użytkownikom. W ocenie autora niniejszego opracowania, taka zależność nie istnieje. Zgodnie z art. 53 § 2 k.k., wymierzając karę, sąd uwzględnia w szczególności m.in. motywację i sposób zachowania się sprawcy oraz jego właściwości i warunki osobiste. Nie ma zatem żadnych podstaw, aby sprawca, który świadomie popełnił przestępstwo posiadania narkotyków, a fakt jego popełnienia nie wynikał z żadnego wewnętrznego przymusu, zasługiwać miał na łagodniejsze traktowanie ze strony organów wymiaru sprawiedliwości niż osoba uzależniona, której stan był w dużej mierze przyczyną popełnienia przestępstwa. A konkretniej, nie ma podstaw ku temu, aby postępowanie przeciwko takiemu sprawcy miało większe podstawy do umorzenia niż postępowanie przeciwko osobie uzależnionej. Analiza dyrektyw wymiaru kary prowadzi bowiem do zupełnie przeciwnej konkluzji - to postępowanie przeciwko osobie uzależnionej powinno być tym bardziej umorzone aniżeli postępowanie przeciwko rekreacyjnemu użytkownikowi narkotyków.

\section{WNIOSKI}

Nowelizację ustawy o przeciwdziałaniu narkomanii z 1 kwietnia 2011 r. zdecydowanie uznać należy za krok w dobrym kierunku. Projekt nowelizacji, oparty na podstawie dokładnych badań aktowych prof. Krzysztofa Krajewskiego (Wydział Prawa i Administracji UJ), opracowany został przez powołany w tym celu zespół ekspertów.

Od wejścia w życie nowelizacji zmniejszyła się liczba spraw o posiadanie narkotyków rozpoznawanych przez sądy. Ponadto, zwiększył się odsetek umorzeń i warunkowych umorzeń postępowania w stosunku do wszystkich osądzonych spraw za przestępstwo posiadania narkotyków. Taki stan rzeczy wynikać może z samego faktu wejścia w życie nowelizacji, co stanowiłoby jej niewątpliwy sukces. Przedstawione dane statystyczne wskazują jednak, że liczba umorzeń spraw o posiadanie narkotyków, w tym umorzeń na podstawie art. 62a u.p.n. - najważniejszej zmiany nowelizacji - jest wciąż stosunkowo mała. Co więcej, jeżeli postępowanie nie zostanie umorzone na etapie postępowania przygotowawczego, jest mało prawdopodobne, aby następnie zostało umorzone przez sąd.

W uzasadnieniu nowelizacji projektodawca zauważył, iż wprowadzenie specjalnego przepisu powinno spowodować, że umarzanie postępowań w bardzo 
drobnych sprawach zacznie faktycznie występować w praktyce i doprowadzi do rzeczywistego odciążenia organów ścigania (Sejm VI kadencji. Uzasadnienie..., 16). Analiza danych statystycznych wskazuje, że odciążenie to nastąpiło w niewystarczającym stopniu. Przyczyną takiego stanu rzeczy jest przede wszystkim brzmienie art. 62a u.p.n., zgodnie z którym umorzenie postępowania jest jedynie fakultatywne i zależy od każdorazowej oceny prokuratora w konkretnej sprawie. W ocenie projektodawcy, brak automatyzmu powinien zagwarantować indywidualne podejście, a tym samym realizację również innych celów prawa karnego w tym obszarze (prewencja generalna, cele terapeutyczne), w tych wypadkach, które na to zasługują (tamże, 15-16). Dostrzec można jednak pewną niekonsekwencję ze strony autorów projektu, którą określić należy jako próbę naprawienia złej praktyki, kolejną praktyką. U podstaw prac nad nowelizacją leżało bowiem dostrzeżenie, że znaczna część sił i środków Policji została skierowana $\mathrm{w}$ zupełnie niewłaściwym kierunku - ścigania drobnych przestępstw narkotykowych, niemających większego znaczenia dla redukcji nielegalnej podaży narkotyków. Następnie, podjęta została próba zmiany tego stanu poprzez wprowadzenie nowej podstawy umorzenia postępowania, która obwarowana jest szeregiem przesłanek. Nieprecyzyjnie sformułowany przepis stanowiący podstawę umorzenia, w połączeniu z jego fakultatywnym charakterem powoduje, że art. 62a u.p.n. znacznie przegrywa ze skazaniami w ramach tzw. konsensualnych form zakończenia postępowania. W tym kontekście należy powtórzyć za prok. Maciejem Nowickim, iż prokuratorzy będą zawsze podchodzić do możliwości umorzenia postępowania $\mathrm{z}$ większą ostrożnością, jeżeli podstawa prawna nie będzie sformułowana wystarczająco jasno.

Przesłanki, od spełnienia których zależy możliwość umorzenia postępowania na podstawie art. 62a u.p.n., mają charakter ocenny i nie zostały w żaden sposób zdefiniowane. Przykładowo, projektodawca w uzasadnieniu nowelizacji wskazał:

„Tym, co może decydować o przyjęciu, że stopień społecznej szkodliwości czynu uzasadnia skorzystanie z proponowanego przepisu, może być przede wszystkim charakter posiadanego środka, tzn. jego szkodliwość. I tak w przypadku posiadania cannabis, a więc substancji o mniejszej szkodliwości niż wiele innych środków, w ilościach nieznacznych i okolicznościach niestwarzających w zasadzie zagrożenia dla dóbr prawnych osób trzecich, w zasadzie można domniemywać zasadność zastosowania proponowanego przepisu. W przypadku innych środków, ze względu na większe zagrożenie, jakie stwarzają one generalnie dla dobra chronionego, jakim jest zdrowie publiczne, zastosowanie tego przepisu powinno wchodzić w grę znacznie rzadziej, co nie oznacza jednak całkowitego wykluczenia takiej możliwości” (tamże, $13-14)$.

Nie wydaje się jednak, aby prokuratorzy mieli szczegółową wiedzę na temat stopnia szkodliwości konkretnych substancji psychoaktywnych. Przede wszystkim jednak - w żaden sposób nie zostało określone pojęcie „,nieznacznej ilości” środków odurzających i substancji psychotropowych. 
Podczas szkoleń w Białymstoku i Rzeszowie ${ }^{19}$ prokuratorzy wyraźnie wskazywali na potrzebę opracowania stosownej tabeli wartości granicznych. Miałaby ona za zadanie zdefiniować pojęcie „nieznacznej ilości”, określając dokładnie rodzaj oraz ilość konkretnych substancji. Na potrzebę wprowadzenia takiej tabeli wskazywali także rozmówcy wywiadów przeprowadzonych na potrzeby raportu. Wreszcie, w uzasadnieniu nowelizacji wskazano, że wskazówką dla organów stosujących prawo (przede wszystkim organów prokuratury) mogą być wewnętrzne wytyczne zawierające stosowne wartości graniczne. Taka bowiem praktyka rozwiązania tego problemu - jak zauważył projektodawca - stosowana jest w wielu krajach europejskich.

Głównym postulatem płynącym z niniejszego raportu jest zatem konieczność opracowania przez Prokuratora Generalnego stosownych wartości granicznych dla poszczególnych substancji psychoaktywnych, definiujących pojęcie ich „nieznacznej ilości”. W przeciwnym wypadku umorzenia postępowań dotyczących posiadania narkotyków na podstawie art. 62a u.p.n. ograniczać się mogą głównie do sprawców uzależnionych lub używających szkodliwie substancji psychoaktywnych. Nie znajdą jednak w należytym stopniu zastosowania w sprawach tzw. rekreacyjnych użytkowników, co wydaje się sprzeczne z założeniami i celami analizowanej nowelizacji oraz - przede wszystkim - wykładnią literalną art. 62a u.p.n. Dopiero opracowanie przez Prokuratora Generalnego stosownych wartości granicznych - zgodnie z uzasadnieniem projektu - stanowić będzie dokończenie procesu nowelizacji i pozwoli na zakładane przez projektodawcę umarzanie drobnych spraw związanych z posiadaniem narkotyków na jak najwcześniejszym etapie postępowania. Można powtórzyć za projektodawcą: „Rzecz w tym, aby sprawy takie nie przekształcały się w «normalne» postępowanie przygotowawcze, co wykluczyłoby możliwość osiągnięcia spodziewanych efektów nowelizacji w zakresie ekonomii postępowania" (tamże, Sejm VI kadencji. Uzasadnienie..., 15). Co oczywiste, należy oczekiwać, że stosowna tabela wartości granicznych zostanie opracowana na wzór podobnych regulacji występujących w innych krajach europejskich ${ }^{20}$.

19 Piotr Kładoczny (HFPC), Barbara Wilamowska (MS) oraz Piotr Kubaszewski (HFPC, autor niniejszego opracowania), jako autorzy komentarza do u.p.n., przeprowadzili szkolenia prokuratorów prokuratur rejonowych w Białymstoku oraz Rzeszowie. Szkolenia odbyły się w grudniu 2013 r. oraz w lutym $2014 \mathrm{r}$.

20 W Portugalii ustawa precyzuje następujące wartości narkotyków, których posiadanie stanowi wykroczenie administracyjne: 25 g marihuany, 5 g haszyszu, 2 g kokainy, $1 \mathrm{~g}$ heroiny lub 10 pastylek LSD bądź ekstazy.

W Czechach wartości te przedstawiają się następująco: 15 g marihuany; 2 g metamfetaminy; 1,5 g heroiny; $1 \mathrm{~g}$ kokainy; 4 tabletki lub 0,4 g proszku lub kryształków ecstasy; 5 listków, tabletek, kapsułek, pastylek lub kryształków LSD; 5 g haszyszu oraz 40 owocników grzybów psylocybinowych.

W Niemczech wartości graniczne precyzują, kiedy sprawca czynu polegającego na posiadaniu narkotyków ma nie podlegać karze - czyn taki zawsze stanowi przestępstwo. Wartości graniczne różnią się w ramach poszczególnych landów i wynoszą od 5 do 15 gramów marihuany oraz od 1 do 3 gramów kokainy. Regulacja niemiecka jest więc bardzo zbliżona do u.p.n. w jej kształcie po nowelizacji, z tą tylko różnicą, że wartości graniczne zostały tam opracowane. 
Prokuratura powinna dodatkowo przemyśleć zajmowanie się drobnymi czynami związanymi z posiadaniem narkotyków w kontekście nowelizacji k.p.k., wprowadzającej kontradyktoryjny model procesu karnego (Ustawa z 27 września 2013 o zmianie...). Wydaje się, że czas poświęcany przez prokuratorów na sporządzanie aktów oskarżenia oraz podejmowanie innych czynności procesowych w tego rodzaju sprawach powinien zostać spożytkowany na ściganie poważniejszych czynów zabronionych. W związku z tym, umarzanie postępowań na podstawie art. 62a u.p.n. powinno leżeć w interesie samych prokuratorów.

Następnie należy postulować wydanie przez Prokuratora Generalnego wytycznych, aby w każdym przypadku, w którym zachodzą przesłanki przewidziane w art. 62a u.p.n, postępowanie było umarzane, chyba że zachodziłaby jakaś nadzwyczajna okoliczność (okoliczność ta powinna zostać szczegółowo uzasadniona).

Zasadne wydaje się także ponowne rozważenie przez ustawodawcę propozycji HFPC dotyczącej wprowadzenia na poziomie u.p.n. domniemania celu posiadania nieznacznej ilości narkotyku „na własne potrzeby”, jeżeli okoliczności nie wskazują na cel handlowy.

$\mathrm{Na}$ zakończenie raz jeszcze podkreślenia wymaga fakt, iż niniejszy raport został sporządzony na podstawie wszelkich dostępnych w tej chwili danych statystycznych, udostępnionych przez: sądy, Prokuraturę Generalną i - przede wszystkim - Ministerstwo Sprawiedliwości. Dopiero jednak przeprowadzenie badań akt sądowych spraw o posiadanie narkotyków pozwoli na realną ocenę stosowania art. 62a u.p.n. w praktyce.

\section{BIBLIOGRAFIA}

Helsińska Fundacja Praw Człowieka. Opinia z dnia 18 grudnia 2009 r. www.hfhrpol.waw.pl/interwencja/pomoc-osobom-uzaleznionym-od-narkotykow/opinia-hfpc-w-sprawie-projektu-ustawy-o-zmianie-ustawy-o-przeciwdzialaniu-narkomanii.html/ [dostęp 10.01.2016].

Helsińska Fundacja Praw Człowieka. Opinia z dnia 22 lutego 2011 r. www.hfhrpol.waw.pl/interwencja/pomoc-osobom-uzaleznionym-od-narkotykow/parlament-przyjal-nowelizacje-ustawy-o-przeciwdzialaniu-narkomanii.html/ [dostęp 10.01.2016].

Kładoczny, Piotr, Barbara Wilamowska, Piotr Kubaszewski (red.). 2013. Ustawa o przeciwdziałaniu narkomanii. Komentarz do wybranych przepisów karnych. Warszawa: Difin.

Krajewski, Krzysztof. 1992. „W kwestii kryminalizacji posiadania środków odurzających i psychotropowych". Państwo i Prawo 8: 49-57.

Krajewski, Krzysztof. 1999. "How flexible are the United Nations drug conventions". International Journal of Drug Policy 10: 329-338.

Krajewski, Krzysztof. 2007. „Prawo karne wobec narkotyków i narkomanii: Ustawodawstwo polskie na tle modeli regulacji dotyczących narkotyków”. Alkoholizm i Narkomania 20 (4): 434.

Krajewski, Krzysztof. 2008a. „Przestępstwo posiadania narkotyków oraz środki stosowane wobec jego sprawców w świetle badań aktowych”. Alkoholizm i Narkomania 21 (3): 221-234. 
Krajewski, Krzysztof. 2008b. „Przestępstwo posiadania narkotyków w świetle badań aktowych”. Państwo i Prawo 9: 31-45.

Krajewski, Krzysztof. 2008c. Sprawy o posiadanie narkotyków w praktyce sądów krakowskich. Raport z badań. Kraków: Uniwersytet Jagielloński.

Kuźmicz, Ewelina, Zofia Mielecka-Kubień, Jędrzej Stasiowski, Dorota Wiszejko-Wierzbicka. 2009. „Penalizacja posiadania narkotyków - działania instytucjonalne i koszty”. Analizy i Opinie 101: 5. Instytut Spraw Publicznych.

Kuźmicz, Ewelina, Zofia Mielecka-Kubień, Dorota Wiszejko-Wierzbicka (red.). 2009. Karanie za posiadanie. Art. 62 ustawy o przeciwdziałaniu narkomanii - koszt, czas, opinie. Warszawa: Instytut Spraw Publicznych.

Płatek, Monika. Opinia do rzadowego projektu ustawy o zmianie ustawy o przeciwdziałaniu narkomanii oraz niektórych innych ustaw (druk $n r$ 3420). orka.sejm.gov.pl/rexdomk6.nsf/ Opdodr?OpenPage\&nr=3420 [dostęp 10.01.2016].

Prokurator Generalny. Sprawozdanie Prokuratora Generalnego z rocznej działalności prokuratury $w 2014 r$. www.pg.gov.pl/ [dostęp 31.07.2015].

Sejm VI kadencji. Uzasadnienie do projektu nowelizacji ustawy o zmianie ustawy o przeciwdziałaniu narkomanii oraz niektórych innych ustaw. Druk sejmowy nr 3420.

Sierosławski, Janusz. 2004. „Używanie narkotyków przez młodzież szkolną. Wyniki ogólnopolskich badań ankietowych ESPAD 2003". Serwis Informacyjny Narkomania 3: 17-55.

Sierosławski, Janusz. 2005. Używanie alkoholu i narkotyków przez młodzież szkolna. Raport z ogólnopolskich badań ankietowych zrealizowanych w $2005 r$. Warszawa: Instytut Psychiatrii i Neurologii.

\title{
Piotr Kubaszewski
}

\section{THE ACT AMENDING THE PREVENTION OF DRUG ABUSE ACT 3 YEARS AFTER ITS ENFORCEMENT - A REPORT ON APPLICATION}

\begin{abstract}
This study is an attempt to evaluate how the institutions, established by the amendment to the Act on prevention of drug abuse of 1 April 2011, perform in practice. The most important change to the act amended was the addition of Article 62a to the Act. This Article gives a prosecutor and court an option to discontinue criminal proceedings against individuals in possession of small amounts of intoxicants and psychotropic substances intended for private use. Furthermore, the amendment extended a scope of alternative medicinal substances implementing the principle of "treat rather than punish".

The report was compiled basing on any available statistical data provided by: courts, the Prosecution General and most of all by the Ministry of Justice. During the work on the report, a few interviews were done with the people who apply the provisions of the amended act (a policeman, a prosecutor and an advocate) and with a representative of the Ministry of Justice.

The presented statistical data show that the number of discontinued proceedings connected with drug possession including those ones discontinued under Article 62a, is still relatively small. The main requirement arising from this report is the necessity for the Prosecutor General's Office to develop proper limit values for individual psychoactive substances defining the notion of "small amounts".
\end{abstract}

Keywords: drugs, amendment, possession, criminalisation, prevention of drug abuse. 